\title{
CULTURAL ADAPTATION AND VALIDATION OF THE HERTH HOPE INDEX FOR PORTUGUESE LANGUAGE: STUDY IN PATIENTS WITH CHRONIC ILLNESS
}

\author{
Alessandra Cristina Sartore Balsanelli ${ }^{1}$ Sonia Aurora Alves Grossi², Kaye Ann Herth ${ }^{3}$
}

\footnotetext{
${ }^{1}$ RN, MD in Nursing. University of São Paulo School of Nursing. São Paulo, Brasil. E-mail: alessandrasartore@hotmail.com

2 PhD, RN, Faculty. University of São Paulo School of Nursing. São Paulo, Brasil. E-mail: sogrossi@usp.br

${ }^{3}$ PhD, RN, FAAN. Dean, College of Allied Health and Nursing. Mankato MN. kaye.herth@mnsu.edu
}

\begin{abstract}
This study aims the cultural adaptation and validation of the Herth Hope Index, an instrument to measure hope. In this methodological study participated 131 individuals: cancer patients, type 2 diabetes patients and their relatives or care providers. The results confirmed reliability of the scale with Cronbach alpha of 0.834 . The test-retest verified the reproducibility of the scale. The construct validity was established by convergent validity between the Escala de Esperança de Herth (Brazilian version) and the Rosenberg Self-Esteem Scale, and the divergent validity between the Escala de Esperança de Herth and the Beck Depression Inventory. The factorial analysis confirmed three factors though composition different from the original scale. The psychometric properties of the Escala de Esperança de Herth were confirmed and indicate it has potential to be used to measure hope in the Brazilian population.
\end{abstract}

DESCRIPTORS: Life expectancy. Psychometrics. Chronic disease. Validation studies

\section{ADAPTAÇÃO CULTURAL E VALIDAÇÃO DO HERTH HOPE INDEX PARA A LÍNGUA PORTUGUESA: ESTUDO EM PACIENTES COM DOENÇA CRÔNICA}

RESUMO: Este estudo tem por objetivo a adaptação cultural e validação do Herth Hope Index, um instrumento para mensurar a esperança. Neste estudo metodológico participaram 131 indivíduos: pacientes oncológicos, pacientes com diabetes do tipo 2 e seus familiares ou cuidadores. Os resultados confirmaram a confiabilidade da escala com Alpha de Cronbach de 0,834. O teste-reteste confirmou a reprodutibilidade da escala. A validade de construto foi estabelecida pela validade convergente entre a Escala de Esperança de Herth (versão Brasileira) e a escala de auto-estima de Rosenberg, e a validade divergente entre a Escala de Esperança de Herth e o Inventário de Depressão de Beck. A análise fatorial confirmou três fatores, apesar da composição diferente da escala original. As propriedades psicométricas da Escala de Esperança de Herth foram confirmadas e, portanto, ela pode ser usada para mensurar esperança na população brasileira.

DESCRITORES: Esperança de vida. Psicometria. Doença crônica. Estudos de validação

\section{LA ADAPTACIÓN CULTURAL Y VALIDACIÓN DE LA HERTH HOPE INDEX PARA PORTUGUÉS: ESTUDIO EN PACIENTES CON ENFERMEDAD CRÓNICA}

\begin{abstract}
RESUMEN: Este estudio tiene como objetivo la adaptación cultural y validación de la escala Herth Hope Index, una herramienta para la medición de la esperanza. Incluyó 131 individuos: pacientes con cáncer, con diabetes del tipo 2 y sus familiares o cuidadores. Los resultados confirmaron la fiabilidad de la escala con Alfa de Cronbach 0,834. El test-retest confirmó la reproducibilidad de la escala. La validez de constructo fue creado por la validez de convergencia entre la escala de la Esperanza Herth (versión brasileña) y la escala de autoestima de Rosenberg, y la validez divergentes entre la escala de la Esperanza Herth y el Inventario de Depresión de Beck. El análisis factorial confirmó tres factores, a pesar de la distinta composición de la escala original. Las propiedades psicométricas de la escala de la Esperanza Herth se han confirmado y, por tanto, se puede utilizar para medir la esperanza en la población brasileña.
\end{abstract}

DESCRIPTORES: Esperanza de vida. Psicometría. Enfermedad crónica. Estudios de validación 


\section{INTRODUCTION}

Hope is related to wellness, quality of life, life after some serious diagnosis and it brings strength to solve problems and face loss, tragedy, loneliness and suffering. ${ }^{1}$

Hope was conceived at two spheres and six dimensions. The spheres are characterized as generalized hope, i.e., some future benefit, but with uncertain development, and the particularized hope, i.e., hope referring to a certain object. The dimensions of hope are: 1 ) affective: the emotions related to hope; 2) cognitive: thoughts and desires related to hope; 3 ) behavioral: actions taken to make hope come true; 4) affiliative: consists of the relationship with oneself, with the others and with God; 5) temporal: a relation between the past, present and future and hope; 6) contextual: includes personal experiences of the whole life and they are under the influence of the experience of hope. ${ }^{2}$

In a chronic process there are serious conditions where patients and their family members lose hope. Nurses may also lose hope when the death of a patient is imminent. However, hope should not be exclusively focused on the desire of a cure or on some more years to live. Something in the short term can be hoped for, such as a week without pain, calling someone the patient loves, seeing spring once again or waiting for a good, dignified death surrounded by the loved ones. ${ }^{3}$ Then, measure hope in these patients can give subsidy to better nursing care.

Considering that there are currently no instruments available in Brazil with which to assess hope in healthy and ill individuals in their native language (Portuguese), the general objective of this study is to make available in Brazil, in Portuguese, a specific instrument to measure hope. The Herth Hope Index (HHI) was the instrument chosen from among other hope indexes to measure hope because it was based on the multidimensionality of hope. ${ }^{1}$ The specific objectives were to make a cultural adaptation and to validate the $\mathrm{HHI}$ instrument in Portuguese and to use this index in an initial study comparing hope scores among three groups - those with cancer, those with diabetes and their relatives or care providers - exploring the relationship between the levels of hope among the three groups and specific sociodemographic and clinical variables.

\section{METHOD}

This methodological research refers to the cultural adaptation and psychometric validation of the HHI to the Brazilian culture. The adaptation and validation it is common in our way when it does not have a national instrument. ${ }^{4}$ This index was an adaptation of it's parent tool Herth Hope Scale (HHS $)^{1}$ and was based in six dimensions of hope and were combined and used as a framework for generating items for the HHS: a) cognitive-temporal; b) affective-behavioral and c) affiliative-contextual. ${ }^{5}$ Hope, as defined in this model, is "a multi-dimensional dynamic life force characterized by a confident yet uncertain expectation of achieving good, which to the hoping person, is realistically possible and personally significant". 5:41

The items on the HHI are in Likert-format and each item is scored on an ordinal scale from 1 to 4 , where a score of 1 indicates "strongly disagree" and a score of 4 indicates "strongly agree". For analysis, all negative items (item 3 and item 6) were reverse scored so that a higher score would indicate a higher level of hope. ${ }^{1}$ The original English version of the HHI has undergone extensive psychometric testing and use and has been found to be both reliable and valid across healthy and ill populations. ${ }^{1}$

The measuring instrument of this study, HHI, was submitted to cultural adaptation and validation. Phase I of this study was composed of translation, back-translation, committee review and pretest following guidelines for cultural adaptation of an instrument. ${ }^{6}$ The translation of the HHI, English to Portuguese, was done separately by researcher and by a Professor of the Department of Medical and Surgical Nursing of University of São Paulo whose mother tongue is Portuguese. The translators are bilingual and worked independently, only one of the translations was aware of the objectives of the study. After analyzing the two translations and choosing the phrases that expressed better the interpretation, the researcher and her thesis chair completed the first Portuguese version. This version of the HHI underwent backtranslation, Portuguese to English, which involved forwarding it to two translators, an English teacher and an official translator, who separately translated the Portuguese version into English. Both weren't aware of the objectives of the research. Never did either of the translators have any contact with the original version in English. Both back-translations were analyzed by the authors and the expressions which readers could understand more clearly were chosen. This process led to a second Portuguese version. This version was submitted to a commit- 
tee review composed of four healthcare providers who were proficient in English. That committee review was requested to assess the semantic and idiomatic equivalences according to the model created by Lino. ${ }^{7}$ The model contained the items of the original version and the second Portuguese version of the HHI.

The questions that reached at least $75 \%$ of agreement among the judges were deemed equivalent. The items with a lower percentage of agreement were analyzed by taking into account the judges' suggestions. After the required adjustments a third Portuguese version of the HHI was written.

Cultural and conceptual equivalence was not conducted in this study because there are no experts in the hope concept in Brazil. The decision to follow this strategy was based on another Brazilian study. ${ }^{8}$

The third Portuguese version of the HHI was used in the pretest with 8 patients with cancer, convenient sample, who were given information about the instrument and stimulated to speak up their doubts and make suggestions for better understanding. No changes were found in any item after the pretest. The 8 patients think the instrument is easy and understanding. The instrument culturally adapted was called, from then on, "Escala de Esperança de Herth" (EEH) ${ }^{9}$

In Phase 2 of this study an analysis of the reliability and validity of the instrument was conducted. Reliability was assessed by means of testretest with 15 subjects, and internal consistency was assessed by means of the Cronbach alpha with the total sample. ${ }^{10}$ The 15 subjects, cancer patients and healthy caregivers, were chosen because they had appointments scheduled in the ambulatory ward within 15 days (the test-retest interval). The construct validity was assessed through convergent validity by means of a correlation between the scores of the EEH (Brazilian version) and the scores of the Rosenberg Self-Esteem Scale (RSES). ${ }^{11}$ Divergent validity was obtained by means of a correlation between the scores of the EEH and the scores of the Beck Depression Inventory (BDI). ${ }^{11}$ The construct validity was also verified through factorial analysis. ${ }^{10}$ The validation process was possible by applying the third Portuguese version of the HHI to the study's sample.

The research was conducted in the Outpatients Chemotherapy for Adults of São Paulo Hospital, a University Hospital of the Federal University of São Paulo, in the Diabetes Control
Unit of the Endocrinology Department of Clinics Hospital of the Medical School of the São Paulo University and in the Brazilian Association of Assistance to Diabetics. The data were collected from March to August 2006.

The sample was composed of 131 individuals who agreed to participate in the study and matched the following inclusion criteria: to be a patient with cancer; with initial illness or metastasis; undergoing chemotherapy in the ambulatory ward; with or without complications resulting from cancer or its treatment; and aware of the diagnosis; or to have type 2 diabetes mellitus with or without complications being treated in an ambulatory ward; or to be a relative or care provider of patients who belonged to the same socio-demographic context of the patients included in the sample; to be 18 years of age or older; to show cognitive capacity to answer the questions in the instrument; and to have at least six years of schooling. The sample was composed of three groups: cancer patients, type 2 diabetes patients, and a third group with patients' relatives or care providers. The sample calculation was defined from the necessity of at least ten individuals for question of the instrument to be validated, being twelve questions, therefore at least 120 individuals.

Socio-demographic and clinical data were collected by means of three different characterization instruments, one for diabetics, one for cancer patients and one for relatives or care providers. They contained information referring to sociodemographic and clinical characteristics such as gender, age, marital status, religion, schooling, profession, current working status, family income and information on the illness and treatment. These variables were chosen because of their importance in chronic illness.

The Rosemberg Self-Esteem Scale ${ }^{12}$ (RSES) was used to assess self-esteem. It is a 10-statement scale scoring from 0 to 3 where the higher the score, the lower the self-esteem.

The Beck Depression Inventory (BDI) was used to assess depression in the sample. It is an instrument to measure self-evaluation of depression frequently used in research or in the clinic. It is a 21-item scale including symptoms and attitudes. The score in each item varies from 0 to 3 . The cut point depends on the sample. For non-depressive patients scores higher than 15 indicate dysphoria. The word "depression" should be used for scores higher than 20, preferably together with a clinical diagnosis. ${ }^{13}$ 
Data were collected in the waiting room of ambulatory wards mentioned above during or after the routine treatment, after explanations about the study had been given, doubts had been clarified and patients had signed a document stating their free and informed consent.

The self-applicable instruments to assess hope, self-esteem and depression were handed in or read to patients at a reserved physical area to ensure privacy for individual answers.

In the descriptive analysis, the tables of simple and relative frequencies had been used for description of the categorical data. Tables with summary statistics (minimum, average, maximum, mean, standard deviation and standard errors of the mean) had been used for description of the quantitative variable.

The Qui-Quadrado or Fischer test was used to assess the relationship of qualitative variables of the hope scale among the 3 groups. The factorial analysis was used to check whether the factors found by the author of the Herth Hope Index were present in this sample by using a maximum likelihood factor analisis with varimax rotation. The internal consistency of the hope scale was assessed with the Cronbach Alpha. ${ }^{10}$ The level of significance was considered $p<0,05$.

The indices Kappa and intra-class correlation had been used for evaluation of the reproducibility and agreement in the test-retest.

Regarding ethical aspects in research, it is worth highlighting that authorization to make cultural adaptation and validation of the $\mathrm{HHI}$ for the Brazilian reality was obtained from Dr. Kaye Herth, author of the original instrument. It is also worth highlighting that the project was approved by the Ethical Committee of the USP Nursing School number 508/2005.

\section{RESULTS}

In the translation of the HHI from English into Portuguese (Brazilian version) there were small divergences between the two translations and the clearest phrases were chosen. In the back-translation some words were modified. The analysis of the original version and the second Portuguese version of the HHI conducted by the judges brought contributions to further adapt the instrument. No alterations were made in any items after the pretest. The culturally adapted instrument was called, as from that moment, "Escala de Esperança de Herth" (EEH).

As to clinical characteristics, it was verified that among the patients with cancer 19 out of 47 ( $40.43 \%)$ had a diagnosis of breast cancer (women). Hematological illnesses (leukemia, lymphoma and myeloma) represented $23.4 \%$ of the sample with 11 patients, and, gastro-intestinal cancers (colon, stomach) stood for $6.3 \%$ of the sample. On a likert pain scale ranging from 0 (none) to 10 (extreme pain), $48.9 \%$ of the patients with cancer had pain which averaged 6.23 in the previous week. The majority of the patients with cancer (51.1\%) found cancer a limiting illness. The average time since diagnosis was 1.01 years.

Among the diabetic patients, the majority had hypertension $27 / 40(67.5 \%)$ as comorbidity; $16 / 40(40 \%)$ used exclusively oral hypoglycemic agents, 12/40 (30\%) used only insulin, 9/40 $(22.5 \%)$ used oral hypoglycemic agents and insulin, and 3/40 (7.5\%) controlled glycemia only with a diet. Diabetic patients 14/ $40(35 \%)$ thought that diabetes is a limiting illness. The sample had a mean Body Mass Index (IMC) of $28.11 \pm 5.37$, which indicates overweight. The mean time since diagnosis was 13.15 years. The table 1 presents the demographic characteristics of the sample.

Table 1 - Demographic characteristics of the sample. São Paulo-SP, 2006

\begin{tabular}{|c|c|c|c|c|c|}
\hline \multirow[b]{2}{*}{ Variables } & \multicolumn{5}{|c|}{ Groups } \\
\hline & $\begin{array}{c}\text { ONCO } \\
(n=47) \\
n(\%)\end{array}$ & $\begin{array}{c}D M \\
(n=40) \\
n(\%)\end{array}$ & $\begin{array}{c}C P^{*} \\
(n=44) \\
n(\%)\end{array}$ & $\begin{array}{c}\text { Total } \\
\text { (n=131) } \\
n(\%)\end{array}$ & $p$ value \\
\hline \multirow{2}{*}{$\begin{array}{l}\text { Sex } \\
\text { Male } \\
\text { Famele }\end{array}$} & $13(27,7)$ & $16(40,0)$ & $16(36,4)$ & $45(34,4)$ & \multirow[b]{2}{*}{$p=0,454\left(x^{2}\right)$} \\
\hline & $34(72,3)$ & $24(60,0)$ & $28(63,6)$ & $86(65,6)$ & \\
\hline Religion & $21(45,7)$ & $26(65,0)$ & $20(45,5)$ & $67(51,5)$ & \multirow{4}{*}{$\begin{array}{l}p=0,172 \\
\text { (Fisher) }\end{array}$} \\
\hline Catholic & $11(23,9)$ & $5(12,5)$ & $15(34,1)$ & $31(23,8)$ & \\
\hline Protestant & $6(13,0)$ & $2(5,0)$ & $5(11,4)$ & $13(10,0)$ & \\
\hline $\begin{array}{l}\text { Spiritualism } \\
\text { Others }\end{array}$ & $8(17,4)$ & $7(17,5)$ & $4(9,1)$ & $19(14,6)$ & \\
\hline
\end{tabular}




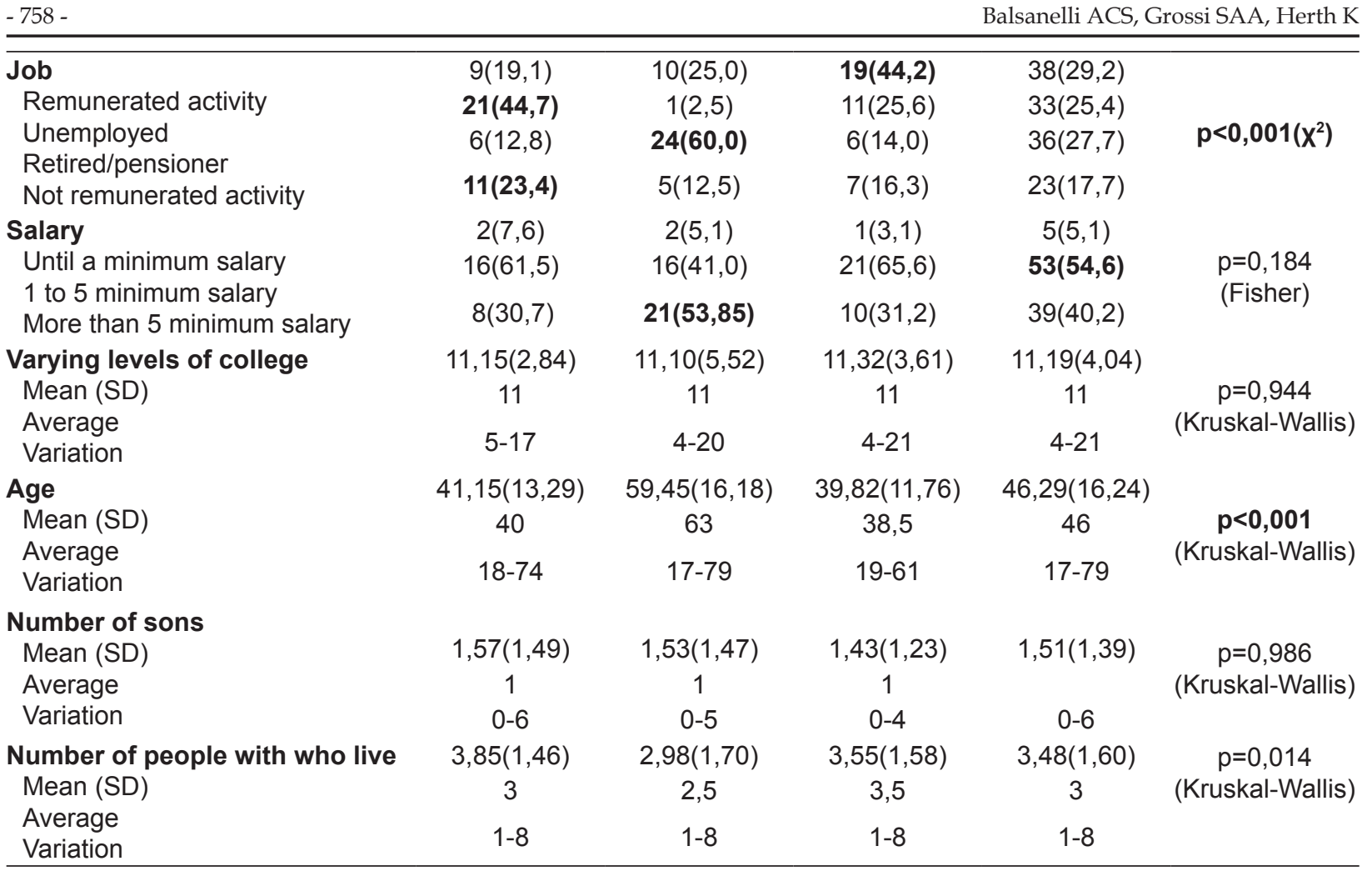

* Care Providers.

The reliability of the EEH was verified by means of an internal consistency analysis and the Cronbach alpha obtained for the full scale was 0.834 . The item 3 of the scale was the one that was the least related to the others; however, if it was removed, it would increase the Cronbach alpha to 0.848 , which would not justify its exclusion. ${ }^{10}$ So, all items should be kept.

The test-retest was conducted with 15 subjects to investigate the stability of the first and second applications of the instrument with an approximate 15-day interval between them. The mean of the indexes obtained in the first and the second applications had a similar result (40.93/ 41.07). It was found that there was no statistically significant difference between the first and the second applications of the EEH $(p=0.97)$. The Intra-Class Correlation Index, usually used to measure reproducibility, resulted in 0.70 for the EEH, which suggests reasonable reproducibility and the value $p=0.001$ significant for that result indicating that there is reproducibility different from a null result.

The construct validity was assessed through convergent validity by using the RSES, and divergent validity by means of the BDI. The factorial analysis was also assessed.

The application of the EEH to the sample studied shows means scores of 40.46 for the group of diabetics, 40.88 for the group of relatives or care providers, and 41.57 for the group of patients with cancer, which are high values considering a possible variation from 12 to 48 where 48 stands for the best hope score. The table 2 shows the similarity of hope escore between the groups.

Table 2 - Hope score between the groups, São Paulo-SP, 2006

\begin{tabular}{cccccccccc}
\hline & Group & Minimum & Average & Maximum & Mean & $\begin{array}{c}\text { Standard } \\
\text { deviation }\end{array}$ & $\begin{array}{c}\text { Standard } \\
\text { error }\end{array}$ & n & -value* \\
\hline \multirow{2}{*}{ EEH } & ONCO & 33 & 42,5 & 48 & 41,57 & 4,60 & 0,71 & 42 & \\
& DM & 31 & 40 & 48 & 40,46 & 4,88 & 0,78 & 39 & 0,348 \\
& Care Providers & 32 & 41,5 & 47 & 40,88 & 3,77 & 0,65 & 34 & \\
\hline
\end{tabular}

The correlation between the EEH and BDI is negative, i.e., the higher the hope score, the lower the depression score. The numeric correlation between the EEH and the RSES scores is negative, 
the higher the hope score, the lower the self-esteem score, once zero for the RSES means a higher score of self-esteem. Therefore, the higher the hope, the higher the self-esteem.
The correlation between the EEH and the two instruments is presented in Table 3.

Table 3 - Correlation among the scores of the EEH, BDI and RSES in the sample, São Paulo-SP, 2006

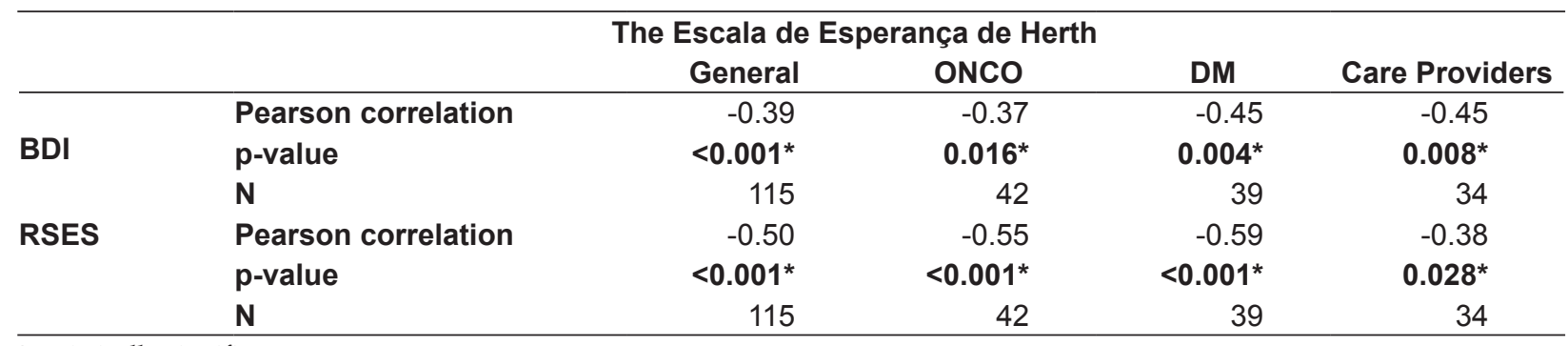

*statistically significant.

The factorial analysis (Table 4) by the maximum likelihood used the same criteria of the author (varimax rotation; self-values higher than 1 , with solution of three factors and criterion of factor selection $>0.40$ ).

The maximum likelihood method used in this study presents only $46 \%$ of variability explained in the first three factors, i.e., less than half of the variability is represented in these three dimensions. With this method virtually one single main factor is obtained encompassing 8 out of the 12 items.

With the method of main component (Table 4) and the same rotation, this explained variability rises to $58 \%$, close to the $61 \%$ found by the author (with the maximum likelihood method). In this method we have the first factor with 8 items, the second with 6 and the third with 2 items, items 5 , 10,11 and 12 being repeated in the first and second factors. By changing the cut-point criterion from 0.40 to 0.50 we have only item 12 repeated in factors 1 and 2. Factor 1 has then 6 items and factor 2 has 5 items. Factor 3 still has 2 items and all the items are presented by the factors (which does not happen with the first method, where item 2 has no load over 0.40 in none of the factors).

Table 4 - Factorial load of the items according to statistic analyses conducted for the EEH, São Paulo- SP, 2006

\begin{tabular}{|c|c|c|c|c|c|c|c|c|c|}
\hline & \multicolumn{3}{|c|}{$\begin{array}{l}\text { Method of maxi- } \\
\text { mum likelihood with } \\
\text { varimax rotation } \\
\text { Author }\end{array}$} & \multicolumn{3}{|c|}{$\begin{array}{l}\text { Method of maxi- } \\
\text { mum likelihood with } \\
\text { varimax rotation } \\
\text { Study }\end{array}$} & \multicolumn{3}{|c|}{$\begin{array}{l}\text { Method of main } \\
\text { components with } \\
\text { varimax rotation } \\
\text { Study }\end{array}$} \\
\hline & F1 & F2 & F3 & F1 & F2 & F3 & F1 & F2 & F3 \\
\hline HHI01: I have a positive outlook toward life. & 0.76 & & & 0.45 & 0.11 & 0.30 & 0.18 & $0.57^{*}$ & 0.35 \\
\hline HHI02: I have short and/or long range goals. & 0.72 & & & 0.31 & 0.30 & 0.18 & $0.52^{*}$ & 0.18 & 0.14 \\
\hline HHI03: I feel all alone. & & & -0.7 & 0.08 & 0.01 & 0.59 & -0.02 & 0.12 & $0.85^{\star}$ \\
\hline HHI04: I can see possibilities in the midst of difficulties. & & 0.81 & & 0.24 & 0.96 & 0.13 & $0.82^{*}$ & 0.01 & 0.14 \\
\hline HHI05: I have a faith that gives me comfort. & & & 0.63 & 0.58 & 0.25 & 0.13 & $0.51^{*}$ & 0.46 & 0.06 \\
\hline HHI06: I feel scared about my future. & -0.81 & & & 0.19 & 0.27 & 0.56 & 0.38 & 0.04 & $0.70^{*}$ \\
\hline HHI07: I can recall happy/ joyful times. & & 0.59 & & 0.46 & 0.02 & 0.13 & 0.01 & 0.76 & 0.10 \\
\hline HHI08: I have deep inner strength. & & & 0.58 & 0.46 & 0.33 & 0.20 & $0.65^{*}$ & 0.23 & 0.14 \\
\hline HHI09I am able to give and receive caring/ love. & & & 0.6 & 0.50 & 0.29 & 0.13 & $0.65^{*}$ & 0.27 & 0.00 \\
\hline HHI10: I have a sense of direction. & & 0.41 & & 0.70 & 0.16 & 0.24 & 0.48 & $0.57^{*}$ & 0.16 \\
\hline HHI11: I believe that each day has potential. & 0.54 & & & 0.72 & 0.25 & -0.04 & 0.40 & $0.72^{*}$ & -0.11 \\
\hline HHI12: I feel my life has value and worth. & & 0.72 & & 0.82 & 0.21 & 0.13 & $0.59^{*}$ & $0.59^{*}$ & 0.05 \\
\hline$\%$ OF EXPLAINED VARIANCE IN 3 FACTORS & $61 \%$ & & & $46.1 \%$ & & & $57.5 \%$ & & \\
\hline KMO & & & & 0.854 & & & 0.854 & & \\
\hline
\end{tabular}

${ }^{*}$ Distribution of factors with cut point at 0.5. 
The KMO (Kaiser-Meyer-Olkin), a test that examines the data adjustment for factorial analysis, had the value of 0.854 for the two analyses conducted, which means that data are adequate.

Level of hope was found not to be significantly related to the cancer diagnosis. For the most frequent diagnoses, breast cancer and hematological illnesses, there was no significant difference $(p=0.216)$ in the hope level. For the pain clinical variable there was not any statistically significant difference either $(p=0.109)$, i.e., as patients with or without pain had similar hope scores.

For diabetics it was verified that in spite of the different forms of treatment received, no significant differences were evidenced among the hope levels among those who used oral hypoglycemic agents, those who used only insulin, and those who used both oral hypoglycemic agents and insulin $(p=0.794)$. As to the comorbidity of arterial hypertension was not found to influence the hope level among diabetic patients $(p=0.512)$.

\section{DISCUSSION}

The studies described the important role hope plays in dealing successfully with chronic illnesses and the significant role that nurses have in implementing interventions to assist ill individuals and their caregivers to maintain and engender their hope. ${ }^{3,5-6}$

Once it was determined that there were no specific instruments created in Brazil or adapted to the Brazilian culture, to assess hope it was decided to adapt and validate an instrument to measure that construct as established in the literature for cultural adaptation. These guidelines have been broadly used to adapt and validate several instruments. ${ }^{4,8-9,12,14}$

The Brazilian version of the HHI did not present significant divergences during the phases through which it was submitted in the cultural adaptation process. Two statements in the instruments have not been changed, item number 5 and item number 10.

The sample presented only two significant socio-demographic differences, the working status among the three groups and the age among the patients.

As to the clinical characteristics of the patients with cancer, the type of tumor and the presence of pain are not significantly related to hope. The presence of associated co-morbidity and the type of treatment for the patients of the group of diabetics was not significantly related to hope either. Another study that also used the HHI did not find differences in the hope score between patients in pain and those who were not in pain. ${ }^{15}$ In that same study the status of the disease did not affect the hope level either. ${ }^{15}$

The analysis of the internal consistency of the original $\mathrm{HHI}$ instrument was conducted in a 172-adult population, 70 out of those with acute illness, 71 chronic patients and 31 terminal patients, obtained internal consistency represented by a Cronbach alpha coefficient of $0.97 .^{1}$ The Swedish study of validation of the HHI which involved 85 adults, 40 out of those being patients with cancer under palliative care and 45 relatives presented in its analysis of consistency an alpha value of $0.88 .{ }^{16}$ In the internal consistency analysis of the EEH a total Cronbach alpha of 0.834 was obtained for the total scale.

The groups are not different as to the total hope score. The groups of patients with cancer, and patients with diabetics and the group of those patients' relatives or care providers had a high total hope score.

The Pearson correlation between the EEH and the score of the BDI and RSES is negative and significant, i.e., the higher the hope score, the lower the depression score, and the bigger the hope score, the smaller the self-esteem score once the score of the self-esteem scale is a reverse score.

The factorial analysis using the method of main components presented a better distribution of the items in three factors. This method with varimax rotation, the explained variance was $58 \%$, similar of author's $61 \%$ (with method of maximum likelihood). In this method the first factor has 8 items, the second 6 and the third 2 items, however the items 5, 10, 11 e 12 repeat in the first and second factors. When changed the cut point to 0.5 , only the item 12 was repeated in the first and second factors.

\section{CONCLUSIONS}

This Brazilian study makes available the Escala de Esperança de Herth, EEH, based on the cultural adaptation and validation in the 131-subject sample composed of chronically ill individuals with cancer and diabetes and their relatives or care providers.

Findings from this study support the initial validity and reliability of the Escala de Esperança de Herth as a tool to measure hope in individuals 
with a chronic illness and their caregivers. Further research is needed to determine the reliability and validity of the Escala de Esperança de Herth in different populations and socio-cultural contexts of the Brazilian culture.

\section{REFERENCES}

1. Herth K. Abbreviated instrument to measure hope: development and psychometric evaluation. J Adv Nurs. 1992 Feb; 17(10):1251-9.

2. Dufault K, Martocchio BC. Symposium on compassionate care and the dying experience. Hope: its spheres and dimensions. Nurs Clin North Am. 1985 Jun; 20(2):379-91.

3. Hickey SS. Enabling hope. Cancer Nurs. 1986 Jun; 9(3):133-7.

4. Viana HB, Guirardello EB, Madruga VA. Tradução e adaptação cultural da Escala Askas: Aging Sexual Knowledge and Attitudes Scale em idosos brasileiros. Texto Contexto Enferm. 2010 AbrJun;19(2):238-45.

5. Herth K. Development and refinement of an instrument to measure hope. Sch Inq Nurs Pract. 1991 Spri; 5(1):39-51.

6. Guillemin F, Bombardier C, Beaton D. Cross-cultural adaptation of health-related quality of life measures: literature review and proposed guidelines. J Clin Epidemiol. 1993 Dec; 46(12):1417-32.

7. Lino MM. Satisfação profissional entre enfermeiras de UTI: adaptação transcultural do Index of Work Satisfaction (IWS) [dissertation]. São Paulo (SP): Universidade de São Paulo, Escola de Enfermagem; 1999.
8. Salvetti MG. Crença de auto-eficácia e validação da "Chronic Pain Self-Efficacy Scale" [dissertation]. São Paulo (SP): Universidade de São Paulo, Escola de Enfermagem; 2004.

9. Sartore AC, Grossi SAA. Escala de Esperança de Herth - instrumento adaptado e validado para a língua Portuguesa. Rev Esc Enferm USP. 2008 Jun; 42(2):227-32.

10. Pereira JCR. Análise de dados qualitativos. São Paulo (SP): Edusp; 1999.

11. Pasquali L. Psicometria: teoria e aplicações. Brasília (DF): Editora Universidade de Brasília; 1997.

12. Dini GM. Adaptação cultural, validade e reprodutibilidade da versão brasileira da Escala de Auto-estima de Rosenberg [dissertation]. São Paulo (SP): Escola Paulista de Medicina, Universidade Federal de São Paulo; 2000

13. Kendall PC, Hollon SD, Beck AT, Hammen CL, Ingran RE. Issues and recommendations regarding use of Beck depression inventory. Cognit Ther Res. 1987 Jun; 11(3):289-99.

14. Santos VLCG, Azevedo MAJA, Silva TS, Carvalho VMJ, Carvalho VF. Adaptação transcultural do pressure ulcer scale for healing (PUSH) para a língua Portuguesa. Rev Latino-am Enfermagem. 2005 MayJun; 13(3):305-13.

15. Chen ML. Pain and hope in patients with cancer: a role for cognition. Cancer Nurs. 2003 Feb; 26(1):61-7.

16. Benzein EG, Berg AC. The Swedish version of Herth Hope Index: an instrument for palliative care. Scand J Caring Sci. 2003 Dec; 17(4):409-15. 